PRE-PRINT: Please cite published version in Philosophy Vol. 91, Issue 4 (2016): 541-557

\title{
Love and Transience in Proust
}

Robbie Kubala

'love is important for the philosopher, full of lessons for whoever analyzes'

Marcel Proust, letter to Lionel Hauser ${ }^{1}$

\begin{abstract}
One strand of recent philosophical attention to Marcel Proust's novel $\grave{A}$ la recherche du temps perdu, exemplified by Martha Nussbaum and Rae Langton, claims that romantic love is depicted in the text as self-regarding and solipsistic. I aim to challenge this reading. First, I demonstrate that the text contains a different view, overlooked by these recent interpreters, according to which love is directed at the partially knowable reality of another. Second, I argue that a better explanation for Proust's narrator's ultimate renunciation of romantic love appeals not to his impossible epistemic standard for knowledge of another person, but to his demanding evaluative standard for the permanence of love. This interpretation takes into account the broader scope of the novel, connecting with its larger themes of lost time and the desire for stability, and is more charitable, connecting to familiar worries about transience and constancy in loving relationships.
\end{abstract}

\section{Introduction}

In the final volume of Marcel Proust's $\grave{A}$ la recherche du temps perdu, the narrator, whom we can call Marcel, renounces romantic love in favor of his literary vocation: 'I intended to resume living in solitude . . . for the duty to write my book [le devoir de faire mon oeuvre] took precedence' (VII, 295; IV, 563). ${ }^{2}$ After having pursued a succession of women - Gilberte, Andrée, Oriane de Guermantes, Mlle de Stermaria, Mme Putbus' lady's maid, and intermittently and finally Albertine - Marcel's failure to forge a lasting relationship intensifies his desire to create a work of art that will endure. One of the many questions

${ }^{1}$ Lionel Hauser was Proust's financial adviser; this letter of 1918 is cited in William G. Carter, Proust in Love (New Haven, GT: Yale University Press, 2006), 55.

2 The first set of Roman and Arabic numerals refer to the volume and page number of the recent English translations published by Penguin Books in 2002: in order, Swann's Way, trans. Lydia Davis; In the Shadow of Young Girls in Flower, trans. James Grieve; The Guermantes Way, trans. Mark Treharne; Sodom and Gomorrah, trans. John Sturrock; The Prisoner, trans. Carol Clark; The Fugitive, trans. Peter Collier, and Finding Time Again, trans. Ian Patterson. Page numbers for the first four volumes refer to the US editions; page numbers for the last three volumes refer to the UK editions, which due to copyright restriction are currently not for sale in the US. I have occasionally modified the translations. The second set of Roman and Arabic numerals refer to the volume and page number of the French Pléaide edition, ed. Jean-Yves Tadié (Paris: Gallimard, 1987-9). 
PRE-PRINT: Please cite published version in Philosophy Vol. 91, Issue 4 (2016): 541-557

the novel raises is this: what kind of view of romantic love could give someone reason to abandon it altogether?

One strand of recent philosophical attention to the novel, exemplified by Martha Nussbaum and Rae Langton, has taken Proustian love as a foil for the philosopher's own preferred account of love. Marcel's various remarks are read as comprising a coherent but misguided theory that we are invited to challenge on independent philosophical grounds. ${ }^{3}$ Thus Nussbaum claims that on Proust's view, love is nothing but 'a rather interesting relation with oneself', ${ }^{4}$ rather than a vulnerable relation to an autonomous other. Similarly, for Langton, Marcel is an epistemic solipsist, believing himself to be the only knowable person and treating the beloved 'merely as a screen on which emotions can be conveniently projected', ${ }^{5}$ rather than opening himself to the possibility of mutual interpretability and its concomitant alterations to his self-conception. ${ }^{6}$

Here, I make two claims by way of response. First, the text also presents a distinct, non-solipsistic view of love, overlooked by these recent interpreters and ultimately rejected by Marcel (although perhaps not by Proust), according to which love is directed at the partially knowable reality of another. ${ }^{7}$ Second, the reason that Marcel does not embrace this more attractive view of love is not, as Langton and Nussbaum suggest, that

3 Nussbaum, 'Love's Knowledge', in Love's Knowledge (New York and Oxford: Oxford University Press, 1990), 261-85, and Langton, 'Love and Solipsism', in Roger Lamb (ed.), Love Analyzed (Boulder, CO: Westview Press, 1997), 123-52.

4 Op. cit. note 3, 272.

5 Op. cit. note 3, 150.

6 The idea that Proustian love is solipsistic has not been conjured from thin air by philosophers, of course, and also finds expression in literary-critical treatments. For instance, Richard Bales claims that 'the Narrator could not provide a bleaker analysis of the nature of love: it is an illusion, created in one's mind by dint of belief in the abstract notion of it' (Proust: $\grave{A}$ la recherche du temps perdu (London: Grant \& Gutler Ltd., 1995), 63).

7 One philosopher from a different tradition who has not ignored this view is Emmanuel Levinas, who in his perceptive 1947 essay 'The Other in Proust' points out that 'Marcel did not love Albertine, if love is a fusion with the Other, the ecstasy of one being over the perfections of the other, or the peace of possession. ... But this non-love is precisely love, the struggle with what cannot be grasped (possession, that absence of Albertine), her presence' (trans. Seán Hand, in Seán Hand (ed.), The Levinas Reader (London: Basil Blackwell, 1989), 160-5 at 164-5). The non-solipsistic view of love that I discuss might be thought of as an elaboration of Levinas' brief but suggestive remarks. 
there can be no knowledge of the beloved, but because love turns out to be just as transient as the soirées and salons that comprise his social life. As Marcel puts it in the first volume of the novel, 'love has such need to find for itself a justification, a guarantee that it will last' (I, 230; I, 218). But he discovers that there are no such guarantees, and when romantic love is assessed at such a demanding standard, its value naturally appears correspondingly minimal.

Following Langton and Nussbaum, I will concentrate on Marcel's relationship with Albertine, especially as recorded in 'Le Chagrin et l'Oubli', the opening chapter of the sixth volume, Albertine disparue. But Marcel's (and perhaps Proust's) passion for generalization means that patterns recur across relationships, and so I will frequently draw on other moments of the novel. One in particular calls for initial comment. 'Un amour de Swann', the novella at the center of the first volume, Du côté de chez Swann, functions as an overture for the hundreds of pages to follow, introducing the novel's central motifs in compressed form, and the relationship of Swann to Odette is explicitly compared with that of Marcel to Albertine. Marcel writes that he takes an interest in Swann's character 'because of the resemblances it offered to my own' (I, 201; I, 191) and foreshadows the parallels very early on by hinting that when it comes to the anguish of love, 'no one, perhaps, could have understood me as well as he' (I, 30; I, 30).

In section 1, I describe Marcel's relationship to Albertine and explain why the solipsistic account of Marcel's renunciation of love has been thought plausible. In section 2, I draw attention to the non-solipsistic view of love - undeniably present in the text, albeit rarely emphasized - as a relation to a partially knowable other. In section 3, I offer an alternative diagnosis of Marcel's renunciation, a diagnosis that appeals not to an impossible epistemic standard for knowledge of another person but to a lofty evaluative standard for the permanence of love.

\section{Love as Solipsism}


PRE-PRINT: Please cite published version in Philosophy Vol. 91, Issue 4 (2016): 541-557

It would be a startlingly revisionary reading of Proust that proposed that love is never depicted as solipsistic. ${ }^{8}$ Indeed, one of the challenges of interpreting Proust is that such a welter of views is to be found in the Recherche. Proust originally intended to write an essay, perhaps in emulation of his early hero John Ruskin, and the novel that resulted is full of general statements that can seem to have been lifted from the pages of a treatise in aesthetics or epistemology. Yet these statements often contradict one another, or contradict an attitude expressed in the depiction of concrete events. ${ }^{9}$ One of my strategies, in highlighting the non-solipsistic view of love, will be to show that some of the maxims that purport to endorse solipsism are unintelligible in the light of Marcel's other thoughts and actions.

By solipsism, Langton and Nussbaum primarily mean epistemic solipsism, the view that one is the only knowable person. Langton claims that Marcel is also, at least sometimes, a metaphysical solipsist, believing himself to be the only person, and a moral solipsist, believing himself to be the only person who matters. It is admittedly difficult to work out the precise logical connections between these varieties of solipsism, but it is not the case that, as Langton puts it, 'Marcel becomes an epistemological solipsist because he began as a moral solipsist of a certain kind, the kind . . . who desires a person not as a person, but as a person to be possessed'. ${ }^{10}$ For one thing, although he can be selfish and

${ }^{8}$ I should emphasize from the outset that while I grant that the Langton-Nussbaum view has some textual support, it is notably ahistorical. A fuller treatment of the solipsistic view would discuss some of its historical antecedents, which within the French tradition alone stretch from Racine's assumption that the lover's view of the beloved is inherently unstable to Stendhal's theory of crystallization, which claims that we love idealized fantasies rather than real people. For a brief but helpful summary, see Alison Finch, 'Love, Sexuality, and Friendship', in Richard Bales (ed.), The Cambridge Companion to Proust (Cambridge: Cambridge University Press, 2001), 168-82. A fuller treatment of my own transience view would similarly have to make reference to its own historical antecedents, from medieval French poetry to Flaubert.

${ }^{9}$ Joshua Landy makes use of this fact in formulating his methodology for reconstructing the views of Proust from those of his narrator Marcel: assume, for any given maxim spoken in Marcel's voice, that Proust endorses it, unless there is a contradiction between maxims or between a maxim and the depicted events (Philosophy as Fiction: Self, Deception, and Knowledge in Proust (New York and Oxford: Oxford University Press, 2004), 35). While I applaud Landy for attributing a greater degree of self-awareness to Proust than many critics do, I am less interested to learn exactly what Proust meant (a task better suited to a literary scholar) than to think through the consequences of a line of thought present in his text.

${ }^{10}$ Langton, 'Love and Solipsism', in Sexual Solipsism: Philosophical Essays on Pornography and Objectification (New York and Oxford: Oxford University Press), 357-81 at 373. 
jealous, Marcel does not begin as a moral solipsist: he has a deep love and noninstrumental concern for the well-being of his family members, especially his mother and grandmother, and at the time of his early romantic encounters, 'love had seemed to be a thing that was not only external, but achievable [non pas seulement exterieure, mais réalisable]' (II, 509; II, 283-4). For another thing, his tendency toward epistemic solipsism is both chronologically and explanatorily prior: the very first paragraph of the novel describes the young Marcel's inability to discern sleep from wakefulness, foregrounding his quest to reach the limits of subjectivity and emerge into an intersubjective world. And in love, it is Marcel's uncertainty about whether the women he loves really are the way he perceives them to be that leads him to treat their qualities as mere projections and to believe his feelings for them to be caused by those projections.

Consider Albertine, one of a group of petit bourgeois girls whom Marcel first encounters in the novel's second volume, when he spends the summer at the seaside resort of Balbec. He befriends the whole group, but his affections - after many twists and turns - eventually settle on Albertine in particular, although his relationship to her is inflected by possessiveness, jealousy, and an anxious suspicion that she is secretly enjoying lesbian trysts. In the fifth volume, La prisonnière, Marcel takes Albertine into his Paris apartment, where he can better supervise her activities, and at the start of Albertine disparue he receives the news that she has fled his smothering machinations. Despite the fact that he had grown weary of life with Albertine and was considering ending the affair, her flight turns out to occasion a fresh bout of possessiveness and a desire to bring her back, a desire that persists even after he learns, several weeks later, that she has been thrown from a horse and killed.

During this period, as throughout the novel, it is not difficult to find expressions of a belief in 'la nature subjective' of love, as Marcel puts it (VI, 401; IV, 17). For instance, there is the idea that our affective responses to the beloved are not caused by any of her properties: 'her person itself has little to do with it; it is almost entirely concerned with the sequence of emotions and anxieties which chance made us feel for her at some time or other in the past, and which habit has attached to her' (VI, 400; IV, 16). Then there is the 
notion that we cannot even detect the properties of the beloved but merely project our own: 'When we speak of a woman's "kindness", we are probably only projecting outside ourselves the pleasure that we feel on seeing her' (VI, 463; IV, 78). And finally there is the solipsistic conclusion: 'The links between another person and ourselves exist only in our minds' (VI, 418; IV, 34).

Yet each of these claims is called into question by others. Marcel recognizes that his romantic history demonstrates that he is responding to the properties of another person:

I could say that I might have experienced the same exclusive love for another woman, but not absolutely any other. For though Albertine, who was plump and dark, did not resemble Gilberte, who was slender and red-haired, both none the less shared the same robust health, the same sensual cheeks and the same enigmatic look. ${ }^{11}$ (VI, 468; IV, 83)

It is significant that physical properties be included in the specification of his 'type', because these cannot be projected in the way that personality properties, which are often more evaluative than descriptive, can. What feeling could Marcel project that would correspond to an experience of Gilberte as having red hair, as opposed to dark hair? As one early critic puts it, in all the relationships of the novel, 'the lover's fantasies are accompanied by more or less objective characterizations of the loved one'. ${ }^{12}$

Not only does love respond to the properties of the beloved; it can even hone our ability to detect them, as in a passage when Marcel is getting to know the band of jeune filles en fleur:

Loving sharpens discernment and our power to make distinctions. [Aimer aide à discerner, à differencier]... When I chatted with one of the girls, I noticed that the outline of her individuality, original and unique, was ingeniously drawn and ruthlessly imposed upon me as much by the

\footnotetext{
${ }^{11}$ Marcel claims, in this context, that everyone falls in love with a certain type, 'although the type may be loosely defined' (VI, 468; IV, 84), but this is contradicted elsewhere. In Le Temps retrouvé, there is a lengthy passage discussing men who love women 'qui n'étaient pas leur genre' (VII, 331; IV, 599), and the final sentence of 'Un amour de Swann' reminds us that Odette was not a woman of Swann's type. For further discussion, see Landy, op. cit. note 9, 28-32.

12 Leo Bersani, Marcel Proust: The Fictions of Life and of Art (New York and Oxford: Oxford University Press, 1965), 127-8.
} 
PRE-PRINT: Please cite published version in Philosophy Vol. 91, Issue 4 (2016): 541-557

modulations of her voice as by the shifting expressions of her face. (II, 486-7; II, 261)

The language is worth some attention: not only is there no suggestion of projection, but the woman's individuality positively imposes itself on Marcel, in a sensory impression that commands his assent. Gilles Deleuze emphasizes this feature of Proustian love: 'To fall in love is to individualize someone by the signs he bears or emits'. ${ }^{13}$ Although presumably there are other relations that facilitate the individuation of others, there is no indication that love entails projecting one's own signs onto another.

Finally, other passages call solipsism in question altogether, proposing not only that a lover can know the beloved through her properties, but that those properties are the means by which her individual essence becomes visible. In the early stages of their relationship, Swann is enchanted by everything about Odette, including her dubious aesthetic tastes, which are 'so many particular traits by which the woman's essence [l'essence de cette femme] appeared to him, became visible' (I, 254; I, 242). Marcel, encountering Albertine in Balbec, echoes this view: 'The object of our anxious investigations is her essence, not to be confused with peculiarities of character [plus essentiel que ces particularités de caractère]' (II, 473-4; II, 249). Considering her glittering blue eyes, what he is 'most aware of is that she herself lies behind them, with her desires, her likes and dislikes, the power of her inscrutable and inexhaustible will [volonté]' (II, 376; II, 152). As it happens, this view of love is not so far from one peak of the contemporary philosophical landscape: it resembles nothing so much as David Velleman's Kantian view, on which the immediate object of love is the manifest person, with her sensorily available qualities, who disarms our emotional defenses and whose personhood we see through those qualities. ${ }^{14}$ Though the immediate object of love is a person's particular traits, the proper

\footnotetext{
13 Deleuze, Proust and Signs, trans. Richard Howard (London: Continuum, 2008), 5.

14 Velleman, 'Love as a Moral Emotion', Ethics 109 (1999), 338-74 at 371.
} 
object of love is the person's 'intelligible essence', her 'rational will'. ${ }^{15}$ Read in this light, Marcel's use of the term 'will' is striking. ${ }^{16}$

Yet if Marcel's end is Kantian, his means are not. Langton is surely right to point out that Marcel evinces an invasive desire to possess Albertine, squirreling her away in his apartment and keeping watch on all her movements. Langton describes Marcel's mental process as follows:

First there was the dim awareness of another life. She exists. Then: If she exists, I can know her. I want to know her. Then: If I can know her, I can possess her, since knowing is possessing. I want to possess her. Discovery: I cannot possess her. Marcel performs a gruesome modus tollens. I cannot possess her. Therefore I cannot know her. Therefore she does not exist. And he contents himself with this conclusion, instead of treating it as the reductio of his strategy, his equation of knowledge and possession. ${ }^{17}$

This is a compelling diagnosis of Marcel's error, if we can allow ourselves to call it that. But I will suggest in the third section that it is not the best interpretation of why he renounces love. My aim in the next section, however, is to present the non-solipsistic view of love that Marcel considers and even acts upon.

\section{Love as Vulnerability}

Nussbaum, raising the issue of solipsism, writes that 'the novel as a whole discourages optimism about knowledge of another within personal love'. ${ }^{18}$ I want first to deny this claim, by insisting that Marcel in fact knows a lot about Albertine, before going on to make the stronger point that the text also depicts love as the relation of mutual openness and vulnerability that recent philosophers so very much want it to be.

\footnotetext{
15 Ibid., 344.

16 This is not the only similarity between Kant and Proust. In a recent paper, Richard Moran argues that Proust shares the Kantian idea that beautiful objects make normative demands on their beholders, albeit without Kant's insistence on universal agreement as criterial of the judgment of beauty ('Kant, Proust, and the Appeal of Beauty', Critical Inquiry 38 (2012): 298-329).
}

17 Op. cit. note 10, 376.

18 Op. cit. note 3, 274 n. 18. 
PRE-PRINT: Please cite published version in Philosophy Vol. 91, Issue 4 (2016): 541-557

We have already seen that Marcel's love of Albertine allows him to make precise discriminations about her physical properties. ${ }^{19}$ But he also learns quite a bit about her personality. He discovers that she is 'très intelligente' (II, 464; II, 239), that she has 'lively and slightly provincial qualities' (II, 508; II, 282), and, after she spurns his physical advances, that she is more virtuous than he had hypothesized (II, 518; II, 292). He is also familiar with quite specific habits that are only revealed over time, such as 'her habit of using a single action to give pleasure to more than one person' (V, 361; III, 892) and 'the alacrity with which she seized upon any opportunity of pleasure' (V, 362; III, 892). That Albertine is simultaneously a hedonist and an inveterate people-pleaser, ready to sacrifice her own aims in order to satisfy the desires of others, is a consequential piece of psychological knowledge, perhaps not even transparent to Albertine herself. Although at times Marcel is tempted to interpret Albertine according to the 'idée fixe' that Odette represents (IV, 201; III, 200), he resists this parallelism by recalling the 'abyss between Albertine, a girl from quite a good bourgeois family, and Odette, a cocotte sold by her mother from an early age' (IV, 229; III, 228). Again, love enables him to make distinctions, to individualize, to make him less blind to the reality of another.

Beyond this, Marcel acknowledges that he and Albertine have developed over time: 'if I had changed my attitude towards her, she herself had also changed' (VI, 469; IV, 84). She speaks in a more lofty register (V, 11; III, 527) and cultivates her tastes (V, 159; III, 682). But not only has she changed; she has changed because of him. His influence transforms her into 'that divine thing [cette chose divine]: a person with whom I could discuss everything' (VI, 464; IV, 79). He even recognizes that this has implications for the solipsistic view of love: 'this long complaint of the soul which believes that it lives enclosed within itself is only superficially a monologue, since the echoes of reality cause it to

\footnotetext{
${ }^{19}$ One charming instance of this is Marcel's early inability to remember where Albertine's beauty mark is: 'Just as a phrase of Vinteuil that had delighted me in the sonata, and which my memory kept moving from the andante to the finale, until the day when, with the score in hand, I was able to find it and localize it where it belonged, in the scherzo, so the beauty mark, which I had remembered on her cheek, then on her chin, came to rest forever on her upper lip, just under her nose' (II, 456-7; II, 232).
} 
change tack' (VI, 466; IV, 82). What seemed like a monologue turns out to be a genuine dialogue in which Marcel and Albertine change each other over time.

For he himself is also open to being changed by her. We see this in minor, everyday activities, as when Albertine helps him to select a dinner menu (III, 383; II, 681) or when they engage in lengthy conversations about Hardy and Dostoevsky (V, 348-52; III, 87883). Their shared love makes him reevaluate his preferences: although Marcel finds a certain Barbedienne bronze hideous, Albertine's awe of it, as he puts it, 'was transferred to me in the form of an admiration which, since it came from Albertine, was important to me, . . . since I loved Albertine' (V, 159; III, 682). This openness is also evident in the first stages of Swann's love for Odette, when Swann's goal is the 'closeness of two hearts [rapprochement des coeurs]' (I, 204; I, 193): 'now that he loved Odette, to feel what she felt, to try to share but a single soul between the two of them [tâcher de n'avoir qu'une âme à eux deux lui était si doux], was so sweet to him that he sought to enjoy the things she liked' (I, 255; I, 242-3). Here we find an expression of the idea, common in the recent philosophical literature, that loving gives one reason to make another's ends one's own, even if one would not otherwise value those ends. ${ }^{20}$ This applies not just to objects, as with the Barbedienne bronze, but to people. Although Swann is much more refined than the Verdurin 'clan' to which Odette belongs, he tries 'to attribute real merits to it' (I, 256; I, 243), even though 'the qualities that he believed to be intrinsic to the Verdurins were merely the reflection of the pleasures he enjoyed in their house because of his love for Odette' (I, 257; I, 244). This is the kind of lighting up of the lover's world that, in more recent work, Langton has described as projection going well. ${ }^{21}$

In love, as Marcel writes, we invest in another person 'such possibilities of causing us pain and joy' (I, 244; I, 232). In the face of all the pain that love causes him, a retreat to solipsism, such as Langton envisages, could seem to offer palpable relief. Yet the reason

\footnotetext{
20 See, for two otherwise quite opposed perspectives, Niko Kolodny, 'Love as Valuing a Relationship', Philosophical Review 112 (2003), 135-89, and Harry Frankfurt, The Reasons of Love (Princeton and Oxford: Princeton University Press, 2004).

${ }^{21}$ Langton, 'Projected Love', in Susan Wolf and Christopher Grau (eds.), Understanding Love: Philosophy, Film, and Fiction (New York and Oxford: Oxford University Press, 2014), 141-62 at 148.
} 
Marcel does not discover the truth about Albertine's sexual desires is not her intrinsic unknowability, but something much more prosaic: his jealousy of her. 'If only I had seized the time before she knew I was jealous of her to ask her the things I wanted to know', he laments (V, 49; III, 566). Solipsism seems to be an attempt at a profound rationalization of a more commonplace experience rather than a settled epistemological view. Swann, whose character is supposed to resemble Marcel's own, is not anxious about the prospect of solipsism, after all, but afflicted by run-of-the-mill sexual jealousy.

\section{Love as Transience}

One safe claim to make at this point is that there is a tension between the two (at least) views of love depicted in the text. The critic Leo Bersani, in what remains one of the best commentaries on the novel, puts it more forcefully: 'There is a certain contradiction between Marcel's exasperated sense of constantly projecting the same desires on an elusive reality with which he can never establish an authentic contact, and the narrator's portrayal of his responsiveness to particular situations'. ${ }^{22}$ In her first paper on Proust, Nussbaum acknowledges the 'unresolved contradictions' pertaining to Proust's treatment of love, ${ }^{23}$ yet her later work retreats from this admission, arguing instead that 'the novel as a whole . . a appears to endorse Marcel's solipsistic conclusion'. ${ }^{24}$

In the face of this tension, we are left with several answers to the question with which we began: what does Marcel believe about romantic love that leads him to abandon its promises? Langton's explanation is that he equates possession with knowledge, only to conclude that both are impossible. A more deflationary account could suppose, as I hinted above, that the narrator's maxims represent a rationalization, taking peculiar features of his own psychology (in particular, a controlling jealousy) and generalizing them into universal truths. The deflationary explanation might have some

\footnotetext{
22 Op. cit. note 12, 122.

23 Nussbaum, 'Fictions of the Soul', in Love's Knowledge (New York and Oxford: Oxford University Press, 1990), 245-60 at 257.

${ }^{24}$ Op. cit. note 3, 274 n. 18.
} 
plausibility were Marcel a real person, but in a densely plotted literary work, one can reasonably hope for something more compelling. I suggest a different approach: Marcel's deepest fear is not solipsism but impermanence, and it is his discovery that even his feelings for Albertine can ebb away that finally pushes him toward the less transient realm of literary creation.

For one thing, it is not as though solipsism is a late-breaking possibility for Marcel. He has flirted with it from his earliest experiences of love. He describes the attraction of the view at the time when he was an adolescent playing with Gilberte: 'At the ChampsÉlysées I had had an inkling, which since those days had become clearer to me, that when we are in love with a woman all we are doing is projecting onto her a state of our own self' (II, 414; II, 189). Already, his 'notion of love had undergone a change' (II, 503; II, 278) from a belief in the possibility of contact with another person to a belief in 'the purely subjective nature [le caractère purement subjectif] of the phenomenon of love' (II, 40; I, 459). What is a discovery is that even his feelings for Albertine are transient and that he can outlast them. Albertine is portrayed as 'the great love of [his] life' (II, 493; II, 268), the subject of his 'grand amour' (III, 389; II, 688), and 'ce plus vaste amour' for which 'all [his] previous loves had been mere, slight essays' (V, 231; III, 757). And yet at various points, both before and after her death, he finds that he no longer feels love for Albertine, that he no longer experiences joy and suffering because of her. His explanation for this has nothing to do with solipsism: 'it is because memories do not remain true for ever, and because life itself is made up of the endless renewal of cells, that love is not eternal' (VI, 557; IV, 172-3). Given the transience of his love, not just for Albertine but for his adored grandmother, the only reasonable course of action is to transcribe that feeling into a work of art, thereby producing 'an acquisition of lasting value for all human beings' (VII, 212; IV, 482). After all, 'nothing can last unless it is generalized [rien ne peut durer qu'en devenant général' (VII, 214; IV, 484).

To be sure, the worry about transience is not a late discovery, either. But Marcel's expectations of love's permanence are curiously lofty. Even with respect to Gilberte, his first romantic interest, Marcel is anxious about the duration of his love: 
PRE-PRINT: Please cite published version in Philosophy Vol. 91, Issue 4 (2016): 541-557

I detested the thought that one day I might have these same feelings for someone else, as this deprived me not only of Gilberte, but also of my love and my pain, the very love and pain through which, as I wept, I tried to grasp the real Gilberte, though I was obliged to admit they did not belong to her in particular, but would sooner or later devolve to some other woman. (II, 186-7; I, 600)

The worry here is not solipsism - he does not fear that he cannot grasp the real Gilberte but transience: Marcel could only accept that his feelings were real if they were permanent. And indeed, the state of affairs he fears comes to pass, when two years later he reaches 'a state of almost complete indifference toward Gilberte':

I would reflect sadly that the love one feels, insofar as it is love for a particular person, may not be a very real thing, since, although an association of pleasant or painful fancies may fix it for a time on a woman, and even convince us that she was its necessary cause, the fact is that if we consciously or unconsciously outgrow those associations, our love, as though it was a spontaneous growth, a thing of our own making, revives and offers itself to another woman. (II, 221; II, 3)

The metaphysical anxiety here is not that others are not real, but that love isn't, more precisely love of particular people. Marcel later says, 'only my love, dedicated to different beings, had lasted' (VII, 211; IV, 481), but here he is referring to love more generally, as an affective disposition, and not to particular instances of love that have determinate objects. Every particular instance of love is transient: feelings always fade, whether because a relationship ends or the beloved passes away. If one can so easily love again, and can know that, what kind of attitude should one take to one's current love?

This concern should not be thought unique to Marcel. In an illuminating recent discussion, Dan Moller tries to make sense of the phenomenon of resilience in the face of the death of loved ones. ${ }^{25}$ Social psychologists have found that although of course spouses and partners initially grieve, they very quickly adapt to loss; the vast majority return to baseline metrics of well-being within two months, and one study reported that fully half

25 Moller, 'Love and Death', Fournal of Philosophy 104 (2007): 301-16. 
of participants did not display even mild depression. ${ }^{26}$ As Marcel puts it, 'in this world where everything wears out, where everything perishes, there is one thing that collapses and is more completely destroyed than anything else, and leaves fewer traces than beauty itself: and that is grief' (VI, 656; IV, 270).

This is murky territory, as Moller's dialectic brings out. Many people are surprised at the empirical results and suspect that people are not properly mourning the death of their loved ones. That insufficient grieving in turn seems to indicate that 'the one suffering the loss never valued the object sufficiently in the first place. ${ }^{27}$ At the same time, it seems foolish to claim that rapid resilience reflects a prior absence of any concern for the beloved; rather, the best explanation for the phenomenon would point to the powerful adaptive mechanisms that we possess for coping with loss. Still, the adaptive explanation does not entirely assuage the uncomfortable reaction to these findings, and the worry remains that the beloved does not 'possess the kind of importance' that we thought he or she had. ${ }^{28}$ Moller's discussion ends inconclusively: because grief can be overcome more easily than our judgment of the importance of others would lead us to believe, our embrace of the phenomenon of resilience 'should be an uneasy one at best'. ${ }^{29}$

Marcel clearly falls into the camp of those who are unswayed by the adaptive explanation, and this reaction makes more sense if we attribute to him the conception of love as a vulnerable relation to an independent other. For if love is merely an interesting relation to oneself, and we construct others according to our imaginative whims and desires, then why wouldn't one celebrate the brevity of grief? That Marcel is troubled by the transience of le chagrin et l'oubli suggests that his fear that the love of particular people is unreal is downstream of his demanding standards for love's permanence, not his belief

\footnotetext{
${ }^{26}$ See George A. Bonnano, Judith Tedlie Moskowitz, Anthony Papa, and Susan Folkman, 'Resilience to Loss in Bereaved Spouses, Bereaved Parents, and Bereaved Gay Men', Fournal of Personality and Social Psychology 88 (2005): 827-43 and Sidney Zisook, Martin Paulus, Stephen R. Schuchter, and Lewis L. Judd, 'The Many Faces of Depression Following Spousal Bereavement', fournal of Affective Disorders 45 (1997): 85-95, both cited in Moller op. cit. note 25, 302.

27 Op. cit. note 25, 305.

28 Ibid., 308.

29 Ibid., 313.
} 
that particular people are unknowable. In brief, Marcel renounces love because he discovers that it cannot survive the onslaught of time.

In closing, I will illustrate two more interpretive benefits of highlighting this concern with transience. First, Marcel's desire for permanence manifests also in a desire that his love for a particular person appear necessary. Just before he becomes involved with Albertine for a second time, Marcel pursues Mlle de Stermaria, who stands him up at dinner on the Íle du Bois. He tells himself that, 'had circumstances been very slightly different, my love might have directed itself elsewhere' and that 'it was therefore not - as I was so anxious, so needed to believe - absolutely necessary [nécessaire] and predestined' (III, 390; III, 688). If a particular relationship can be necessary, then, according to Marcel, it is less likely to be transient (note also that he declines to project inevitability onto the relationship, though that would seem to be more soothing to him). After Albertine dies, Marcel reflects sadly that his love for her 'was not necessary [nécessaire], not only because it could have happened with Mlle de Stermaria, but even without that, as I came to know it better, and started to find that it seemed too similar to what it had been for other women' (VI, 470; IV, 85). If his love for Albertine is not unique, then it can be replaced some day.

Second, Marcel's worry about transience applies even to knowledge. As he comes to know Albertine in Balbec, he reflects:

To achieve accurate knowledge of others, if such a thing were possible, we could only ever arrive at it through the slow and unsure recognition of our own initial optical inaccuracies. However, such knowledge is not possible: for, while our vision of others is being adjusted, they, who are not made of mere brute matter, are also changing; we think we have managed to see them more clearly, but they shift. (II, 453; II, 229)

The first sentence of this passage almost sounds like something out of Iris Murdoch: loving and accurate knowledge of others is possible only through a gradual removal of our needy and selfish distortions. Of course, for Marcel, such knowledge turns out not to be possible. Yet his explanation is noteworthy: we cannot know others not because they are in principle unknowable (which Marcel does not, I have argued, actually believe), or 
even because our possessive desires impede our investigations, but because they are so mercurial. The changeability of others means that our knowledge of them can never catch up to the way they are. Yes, Marcel's jealousy is also an impediment to knowing Albertine - he never does learn whether she has lesbian affairs, after all - but it is not the primary obstacle.

Even before his great affair with Albertine, Marcel knows how he could get himself to abandon love: 'We should be forever cured of our romanticism were we willing, in order to think of the one we love, to try to be the person we shall be once we no longer love them' (IV, 137; III, 135). The cure is not solipsism but simply the knowledge that we can outlast love. The cure becomes a self-fulfilling prophecy, since Marcel becomes someone who no longer loves Albertine, and as it turns out, he did not even need to try. Forgetting, the disruption of old habits, and other 'adaptive' mechanisms do the work for him. He is entirely cured of his romanticism.

\section{Conclusion}

I have drawn one interpretive thread through the tangled skein of Proust's novel, attempting to show that it is both sturdier and more attractive than the thread of solipsism. To some degree, as should already be apparent, the contradictions of the novel make it difficult to sustain any one settled reading. ${ }^{30}$ Yet I believe that my interpretation takes into account the broader scope of the novel, connecting with its larger themes of

\footnotetext{
${ }^{30}$ Again, Bersani is perceptive about this: 'The only way we can miss the point about Albertine is to read the novel as if there were any one, exclusive point to be made about her' (Op. cit. note 12, 137).
} 
lost time and the desire for stability, and that it is more charitable. ${ }^{31}$ Rather than convict Marcel (or even Proust, as Langton and Nussbaum do) of a solipsistic error akin to that of Bertrand Russell's sense-datum theory, emphasizing Marcel's need for constancy in love renders more intelligible his ultimate renunciation of it. Surely all of us who have experienced love have, from time to time, found ourselves searching for guarantees that it will last. For love, like beauty, in Stendhal's memorable phrase, offers only a promise of happiness. ${ }^{32}$ The question facing the lover is whether to act on that promise, as many of us do, or to suspect it of falsity, as Marcel does. ${ }^{33}$

31 Any interpretation of Proust is bound to run up against passages that are simply mystifying, however, and so there are limits to how charitable a reading can be. One such passage comes from the final paragraph of the opening chapter of Albertine disparue: 'When I had understood the difference that there was between the importance of her person and her actions for me as opposed to for others, implying that my love was less a love for her than a love within me, I could have drawn diverse conclusions from this subjective character of my love' (VI, 522; IV, 137). As I see it, the implication just doesn't follow. Unless Marcel is imagining that loving someone entails a Kantian demand for universal agreement as to her lovability, I can see no reason why he should not positively celebrate a state of affairs in which the beloved seems more important to him than she does to others; such a state of affairs is, I take it, partially constitutive of love. And even if he took the Kantian line, there is no reason for him to think that this difference of importance in any way implies that he does not love Albertine. Such reasoning would seem, even more than any kind of solipsism, to be a reductio of the whole notion of love.

32 Alexander Nehamas makes much of this phrase in Only a Promise of Happiness: The Place of Beauty in a World of Art (Princeton and Oxford: Princeton University Press, 2007). He also draws attention to the view of love as vulnerability in Proust, focusing on the relationship between Swann and Odette, though he does not develop the point further with respect to Proust: 'I willingly give you power over myself emotionally, ethically, and intellectually, trusting you not to exploit it. By becoming vulnerable in that way, I put my identity at serious risk because I have no way of telling how our relationship will ultimately affect me and whether it will be for good or bad - and neither do you' (57).

${ }_{33}$ My greatest debt in writing this paper is to Philip Kitcher, for his thoughtful comments and generous encouragement. I am also grateful to Lydia Goehr and Elisabeth Ladenson for helpful discussion. Earlier versions of this paper were delivered at the Love's Passion Workshop at the University of Hertfordshire (September 2014), the Columbia Journal of Literary Criticism Seminar Series (March 2015), the Felician Ethics Conference (April 2015), and the British Society for Aesthetics Conference (September 2015). I am particularly indebted to Gregory Currie, Catherine Elgin, and Jonathan Gilmore for their perceptive and probing questions on that last occasion. 